\title{
PROLEGOMENA TO EVERGETICS
}

\author{
V.A. Vittikh \\ Institute for the Control of Complex Systems of Russian Academy of Sciences, Samara, Russia \\ vav1940@gmail.com
}

\begin{abstract}
The article expounds prefatory remarks and explanatory essay (Prolegomena) to the Evergetics - a valueand subject-oriented science on management processes in the society. The Evergetics seeks reserves to improve management efficiency not in the modernization of an "impersonal" bureaucratic machine, but in the people, in every man, in the use of his intellectual and volitional resources. The man is considered there not as a "cog" of a value-invariant management mechanism, but as a person (actor), endowed with consciousness, who acts rationally and performs cognitive-activity-related functions together with other people to resolve any problem situations that arise in everyday life. These heterogeneous actors having their own subjective views of the world and value priorities, based on the Poincaré's conventional concept of truth, which treats the truth as a result of an agreement, produce intersubjective knowledge, on the basis of which they make a collective decision on how to settle the situation. Perception of meaning of the situation by each heterogeneous actor happens at the level of individual consciousness. However, one person cannot constitute the whole variety of meanings of the situation, so this person receives from others what lacks in his own experience. Meaning-generating activity of people has an impact on all intersubjective community and, as a result, a common meaning-bearing space appears. A holonic approach is used in the Evergetics (on a "part-whole" principle) to build systems in contrast to the traditional causal approach (on a "cause-effect" principle). The article emphasizes strategic significance of the problem to transform the "Economic Man" to the "Man of Culture".
\end{abstract}

Key words: evergetics, management processes in the society, heterogeneous actor, everyday life, intersubjectivity, problem situation, phenomenology, holonic system, man of culture.

\section{Introduction}

In the middle of the past century, N. Wiener formulated in his monograph "Cybernetics and Society" [1] (as it was stated in [2]) the principles of management organization in a cybernetic society, based on a large use of computer aids in all spheres of human activity, and set forth his view of the results of social life cybernation. We need to take care, he wrote, that "the new modalities are used for the benefit of man, for increasing his leisure and enriching his spiritual life, rather than merely for profits and the worship of the machine as a new brazen calf." Wiener saw in the cyber society a developing society, which (in contrast to the society that supports the status quo) reserves a part of its resources for the development of future generations, because "the more we take from the world, the less we leave in it, and, eventually, we will have to pay our debts at the very moment that may be very unsuitable to ensure the continuation of our lives."

In a society in which the automatic devices are involved in the processes of preparation and making decisions and "know" how to perform the functions entrusted to them, N. Wiener writes that there is one quality which is more important than "know-how", this is "know-what" by which we determine not only how to accomplish our purposes, but what our purposes are to be. This selection of goals, objectives, criteria and limitations should be done not by a "machine à gouverner/controlling machine", but by human beings, who, dependently of their value reference points, may use the achievements of the second industrial revolution "both for the good of the mankind and for its destruction". "The hour is very late, and the choice of good and evil knocks at our door", - 
this sentence crowns the Chapter X of the monograph [1]. N. Wiener saw in this choice the major problem, the solution of which people try, as far as possible, to push "for later time", "so long as we can continue to pretend that all is right with the world, we plug up our ears against the sound of ancestral voices prophesying war". At the same time he hoped that "the roots of good will are there" despite the fact that "there are many dangers still ahead".

However, the success of society cybernation was largely due not to the fact that "the world has become kinder", but to the instrumental performance: the widespread use of Informatics and Computer science, often becoming an end in itself, came to the foreground. For example, a total computerization of schools does not mean that pupils, who have mastered to work with computers and obtained access to the Internet, have become more literate and well mannered. It should be recognized that "the worship of the machine as a new brazen calf" yet happened despite the warning of N. Wiener, and the man with his vital needs, spiritual requirements, aspirations for a safe existence and creative development, virtually dropped out of sight of the cybernetic systems creators, who were interested primarily in technical and economic performance of these systems, and only after that comes the so-called "human factor", emphasizing rather "disturbing" role of the man in the processes of functioning of the developed systems [2].

Being translated from Greek as "art of helmsman", the Cybernetics deals with "laying a course", i.e., finding the most effective ways to achieve the goal, but doesn't raise the question of how this goal (and, consequently, the problem to be solved) is consistent with the moral, ethical, or some other kinds of values. The very goal is out of discussion. The cybernetic "helmsman", thus getting the job, seeks, as far as possible, to optimally achieve the goal (let's say, by spending minimum of resources), but doesn't think about humanitarianly and socially significant consequences of the achievement thereof.

In other words, the Cybernetics, as well as classical science of management, using natural science methodology of knowledge, which excludes from consideration the man with his interests and value priorities, are "impersonal" value-neutral science (this refers to the social, general humanitarian values presented by morality, ethics, etc., since classical sciences, as we know, have their own specific value orientations associated with the search for objective truth). This means that it is difficult, almost impossible, to expect that decision-making in public life, carried out at this basis, will be focused on the prevention and settlement of social and humanitarian problems which are topical for the mankind: military threats, economic crises, environmental issues, fight against poverty etc. Attempts to formulate and solve such problems within narrow disciplinary (e.g. economic) models, as the history of mankind demonstrates, give no tangible results.

Therefore, there is a need in the development of a new value-oriented science of management processes in the society, which focuses on the man with his subjective perceptions of the world and search for answers to questions about the meaning and purpose of human existence. The papers [2] and [3] have proposed to call such a science as Evergetics (Greek's evergetics - benefactor), so the subject of this paper is devoted to expound prefatory remarks and explanatory essay (Prolegomena) thereto.

\section{Methodological foundations of evergetics}

The scientific revolution of the 17th century, marked by the birth of classical science, especially Newtonian mechanics, formed an ideal objective-true knowledge acquired by a value-invariant subject, distanced from the object of research and studying it "from outside". In the 18th century, in the age of Enlightenment, the spread of mechanistic science led to its transformation into a mechanistic view of the world, accompanied by a "triumphant march" of rationalism, signifying the faith in the unlimited possibilities of the human mind. Social development became to be directly associated 
with scientific progress. The scientific view of world, established by the time, became the basis of mass education, thus in the 19th century, science became to be considered as a productive force [4].

Impressive achievements of natural science became the reason that the methodology of the natural sciences began to be used in the construction of the social sciences. For example, C.H. SaintSimon and A. Comte considered sociology as "social physics", focused on the search for objective laws of society, similar to the laws of Newtonian mechanics [4]. In this case, the society becomes a kind of a "quasi natural" object, devoid of any manifestations of subjectivity, where the management processes acquire an objective character, just as the autopilot controls the flight of an aircraft without human intervention. But this "objectivist" approach does not meet the definition of a society that is a product of the mind and will of the people who compose it; Society cannot exist without people. It should be noted that E. Husserl in his work "Crisis of European Sciences and Transcendental Phenomenology" saw the root cause of the disease state of science just in the fact that the objective science has lost the man from the focus of attention [5].

Since classical science cannot serve as a model for the construction of the science of management processes in the society, i.e. Evergetics, it is necessary to apply to the postnonclassical scientific rationality, obliged by its birth to the global scientific revolution of the last third of the 20th century [6]. Unlike the natural sciences, the knowing subject is seen here not as distanced from the object being studied, but as being inside it; respectively, a human action is not something external. Postnonclassical type of rationality "takes into account the correlation of acquired knowledge about the object not only with peculiarity of means and operations of activities, but also with value-target structures", and puts in the center of the research "unique, historically developing systems, which include the man himself as a special component thereof" [6]. Therefore, the ideal of a value-neutral research is transformed in the direction of inclusion of axiological (value) factors into the body of explanatory provisions.

Thus, it emerges a concept, important for Evergetics, of a heterogeneous actor, i.e. the person performing any activity-related functions, including cognitive ones, to transform the society, possessing intersubjective consciousness (corresponding to the fact of the existence of other actors), proper interests and a subjective scale of value preferences [7]. Every such actor, in his daily life, is able to perceive himself together with other actors to be in a problem situation. Under the problem situation, we mean a situation where an unsatisfactory state of affairs is already realized, but it is not yet clear what to do to change it [8]. These actors, being based on the Poincaré's conventional concept of truth, which treats the truth as a result of an agreement, produce intersubjective knowledge, on the basis of which a collective decision on how to resolve the situation will be then made. An ordered set of intersubjective knowledge is the basis of ad hoc theory of intersubjective management [7], addressed to a specific situation and developed by the actors themselves.

It should be emphasized one more feature of the methodology of Evergetics: if in classical science of management, the object of research and management is pre-given to the subject, i.e. is primary in relation to it, then, in Evergetics, everything begins from the man-actor, "constructing" the object in his mind, i.e. a situation about which he begins to seek, first of all, answers to the questions "why?" and "what?" to do for settling it, and only then - "how?" to do it. Thus, the organization (or rather, self-organization) of management processes begins by the formation of heterogeneous intersubjective community of actors, perceiving themselves to be in their common problem situation and willing to participate in its settlement, i.e. it is just in the Evergetics that a subjectoriented approach to management is developing [9]. 


\section{Intersubjective communities of heterogeneous actors}

Every man is constantly facing the need to solve some problems. Even in the condition where he has seemingly got rid of all the problems, the man is still concerned about the need to preserve this condition. The individual resolves a part of the problems on its own, but, to solve some of the problems, usually the most difficult and time-consuming, he is forced to look for a partner. As a result, explorations and negotiations lead to form an intersubjective community of homogeneous actors, i.e. the people with subjective interests and values, but united by their awareness of belonging to a common problem situation, which they want to settle jointly performing cognitive functions and activities.

Intersubjective community is an aggregate of individuals who have, following [10], "a common understanding, what, within this aggregate, belongs to the public life sphere, and what belongs to the private one". Community, with its "soft", poorly formalized relationships between the people, distinguishing only "mine" and "ours", is being formed in their everyday life, but it is far to be a system where the "elements" are fixed and the links between them are formalized. From this point of view, the man exists simultaneously in the life-world and in the system world.

The concept of "life-world" introduced by E. Husserl is defined as an actuality where the man has been living initially; it is his inalienable reality. The life-world has a subjective-relative nature, wherein all the realities are attributed to the man, and this matter doesn't belong to the natural science, but to the phenomenology [5]. E. Husserl explains that, for example, the historical lifeworld of the Greeks is "not an objective world in our sense, but it is their notion of the world, i.e. their own subjective meaningfulness of all the realities, having a value for them, for example, with gods, demons, etc" [4]. In the A. Schütz's Phenomenological Sociology, the notion of the "lifeworld" is considered as an intersubjective everyday world, as a world of daily life [11].

In the system world, the actors are transformed in any depersonalized "elements" that are in a fixed relationship to each other. In contrast to communicatively structured life-world, which is a sphere of private and public life, the system world, including subsystems of economics and politics, is formally organized [12]. Despite the fact that the modern societies, built on democratic principles, assert the primacy of the life-world over the economic and authoritative subsystems, according to J. Habermas, on the contrary, "a colonization of the life-world is happening: the imperatives of autonomous subsystems, having thrown off ideological veils, conquer, like colonialists coming to a primitive society, the life-world from outside and impose assimilation process to it" [12].

There is a widespread belief that "initially unorganized" life-world (everyday life) needs constant ordering through the creation and practical application of a wide variety of control systems. If some problem appears in people's lives, a management structure is consequently created, which should deal with its settlement. By that time, the problem has already disappeared, but the structure still remains. Moreover, a management structure is often created "for people" who "need" to have jobs in "the power". All this entails an increase in the size and reduce the effectiveness of the administrative apparatus. Systems "colonize" the life-world.

And if speaking of classical management science, it deals with the management processes just in the system world, where everything comes down to design, development, modernization and use of systems [13]. From the middle of the last century until the present day, a systems approach is considered as widely accepted methodological techniques that not only causes, but cannot cause any doubts about the usefulness and high effectiveness of such application thereof. And this, of course, is true, but as long as the system world doesn't lose connection with the life-world. If the system world is closed on itself and develops in the interest of the systems themselves, it doesn't mean at all that society and the people who make it up will be gainer.

For example, systems analysts can improve the system of railway traffic control in terms to save certain resources, which will result in some "system effect" in interest of the railway adminis- 
tration. But it can cause significant inconvenience to passengers who have built their life-world reckoning on the existing, non-upgraded scheme of passenger traffic.

In the system world, the "projections" of people act on functions, positions, powers and interaction mechanisms, inherent to this or that system, as long as a living man from the life-world is aware of his belonging to the system, sharing its "rules of the game". The system is treated by him through the "prism" of accepted theoretical provisions, methodical materials, instructions, used tools, models and so on, which forms the basis for the formalization and modernization of management processes, ultimately, to improve the efficiency of the system. All this corresponds to Weber's doctrine of formal (instrumental) rationality, his depersonalized "ideal bureaucracy". In other words, the system world integrates with instrumental rationality (in contrast to communicatively rational life-world which opposes against cognitive-instrumental narrowing of mind) [12].

In contrast to the classical management science, Evergetics deals with heterogeneous actors forming intersubjective community in everyday life. Thus, each actor, as said above, is at the same time an investigator and a person participating in decision-making, which means that a scientist who studies management processes in the society and who is also an actor, "loses the privileged position of an absolute observer and acts only as a partaker in social life on an equal basis with others", therefore, a number of scientists (including J. Habermas and A. Giddens) "substantiate the idea of re-examination of the social status of science and of the new concept of cognizing subject, to return the language of science "home", in everyday life" [4].

Also, the activist sociology [14] "presupposes a social activity of both professionals and ordinary citizens involved in the transformation of social structures", and consciousness of "the importance to own local and/or situational knowledge, of the need for vision problems "from below" in a specific social and cultural context" And, according to the A. Giddens's sociological concept, every member of society is always a "practicing social theorist" [15].

Evergetics, thus, proceeds from the thesis that knowledge of the problem situation in everyday life is acquired and systematized by the actors themselves being aware to be "inside" of this situation and having organized themselves in the intersubjective community.

It should be noted that "the problems and topics of everyday life (daily life of people) are generally ignored and slighted as lying outside the scientific disciplinarity ... Meanings, shared "by everybody" in everyday situations, form the world of primary typified (anonymized) meanings, operation by which allows to combine the perspectives of figures (actors) acting as "ordinary sociologists" ... Beyond of (primary) world of everyday life, there are (secondary) fields of professionalized "ultimate semantic spheres", the values of which are accessible in full only for those figures (actors) who are specialized in these spheres and are involved therein, but "opaque" for the "uninitiated" [16].

In other words, everyday life is considered as a primary "undifferentiated integrity", and narrow, divided among themselves, professional spheres of activity - as a secondary one [17]. Accordingly, heterogeneous actors originally "immerse" in a life problem situation, form intersubjective community and seek to understand the meaning of the situation, acting as ordinary people with all their subjective peculiarities, intellectual potentialities and ideas about values. However, these "everyday researchers" work out in common intersubjective knowledge about the current situation, on the basis of which the decisions are made about what tasks need to be achieved for its settlement. After that, the "world system" enters into work, where narrow professionals begin to operate, but the same actors from the "world of everyday life" may act in this quality, too. 


\section{Meaning of the problem situation}

The man in the social life is always in some situations. As suggested by Jean-Paul Sartre, "the situation - it is my position in the world, defined by relationships of usability and resistibility of those realities that surround me ... The structure of the situation is composed of "my place", "my body", "my past", "my position relative to others" and "my fundamental attitude to the other" [5]. The situation is seen as a problem if I'm not satisfied by something in it and I have no methods and no means to change it. Then, first of all, it is necessary to constitute the meaning of the problem situation ("to constitute" means an intentional, i.e. directed at an object, meaning-forming activity [11]). The representative of the phenomenological trend in philosophy of the 20th century, Maurice Merleau-Ponty recognized "creation of meaning as a fundamental feature of the Being and of the human existence" [4].

Perception of meaning of the situation by each heterogeneous actor happens in its own way, at the level of individual consciousness. However, one person cannot constitute the whole variety of meanings of the situation, so this person receives from others what lacks in his own experience. Meaning-generating activity of people has an impact on the whole intersubjective community in which the man exists, and, as a result, a common meaning-bearing space appears. Participants of the situation, thus, endow meanings to the objects of the situation, giving them the status of values, rather than considering them as physical objects.

A city is given in [18] as an example of an intersubjective meaning space. Urban environment depends on meaning-setting acts of people who live in it. And this environment bears primarily a cultural, rather than physical, character: urban objects - buildings, streets, monuments - have value status, the people give them meanings. Value status of these objects occurs at the intersection of perceptions by different people. City exists as a city, i.e. as a kind of internal, meaningful space, only for its inhabitants. A man from another town will perceive it as a simple set of physical objects.

In other words, the man distinguishes the object itself (the "thing") and the notion of it (the concept of the "thing" as a part of knowledge), but the "thing" and the "notion" are as if "transfused" into each other in the same content of consciousness: that's why, for example, Moon and notion of the Moon cannot be strictly separated from each other [5]. Such a consideration of the physical world and the consciousness of an individual as interrelated parts of a single is a characteristic feature of the phenomenology of E. Husserl [19], which is based on the proposition that "every originally given contemplation is a true source of cognition" [4].

Phenomenology proceeds from the principle of premise-free cognition, according to which the cognizing subject must be protected from any outside introduced assumptions. However, according to E. Husserl, "intellectual tradition of European mentality, a habit to look at the world through the glasses of theories, leads to the fact that this transformation of sensual into numerical remains unnoticed ... The science puts the world in the "dress of ideas", in the so-called "dress of objective truths". And we take for a true being what is created by "dress of ideas", products of method - for a living reality" [5]. The above said applies equally to the management science processes in the society where, up to now, there is a domination of the principles of classical rationality, mechanically transferred from the natural sciences. The subject here is distancing itself from the object, holding the position of a detached observer; the subject, for getting "an objectively true" knowledge, explores the object through the "prism" of one or another theory, builds mathematical models, after having experimented therewith, makes decisions on control impacts on the object.

Evergetics opposes a phenomenological approach to such a single-minded focus and a deformed vision of the object-situation by the "torn out" subject [20]: a man-actor, not burdened by various limitations and assumptions, i.e. "from scratch, from tabula rasa", considers the situation from "inside" as an integrity and constitutes its meaning in view of meaning-forming activities of 
other actors also perceiving themselves in this situation and having formed an intersubjective community. Then, the notion itself of "meaning" must be considered in relation to the actor, who is the subject of activity. The meaning becomes a value and characteristics of usefulness of the object for a person, and the meaning is acquired in relation to specific life situations, which is estimated as indefinite due to multiple competing options.

Such an approach was developed by V. Frankl [21], who considered the human desire to find the meaning as an innate motivational tendency inherent in all the people and being the main engine of behavior and personality development. He wrote that the perception of the meaning is "the awareness of opportunities in the background of reality, or, more simply, the awareness of what can be done with respect to this situation". A. Längle specified [22]: "That opportunity, which we distinguish by its value and significance as the best in the circumstances, which bears in itself the fullness of vital existence, is just the meaning of the current moment... The meaning - it is always a realistic path, appropriate to the circumstances ... The meaning in the existential sense is a function of two variables: both each time changing conditions, i.e. opportunities of absolutely determined circumstances, - and properties, abilities, talents of the man who finds himself to be in those circumstances... What is significant for us is meaningful... What we do not care is meaningless".

For example, a problem situation may consist in the fact that a man needs to get to the other side of the river. The situation gives him three options: wait for the arrival of the ferry, walk a few kilometers on foot to the bridge and then cross the river on it, and finally, swim the river across. If the man is not very well, and he has the time to wait, then it would make sense to use the ferry. In the case where time is limited, and he cannot cross the river on his own, it would make sense for the man to overcome walking the distance to the bridge and then to use it for crossing the river to the other side. For a good swimmer, it is a direct sense to swim across the river.

The situation will be essentially complicated, if we assume that there are several persons in this problem situation, and all of them are bound by a restriction: they have to overcome the river together, using a single, common to them all, method of crossing. Then, for them, it can make sense only one of the three options offered by the situation, despite the fact that, initially, each participant of river crossing has seen his own subjective sense in this situation. In order to reach such an agreement, they must undertake complex multilateral negotiations using mutual persuasion, and to find a consensus, having overcome irrationality which is so inherent to the people with its primacy of feelings over reason. Therefore, mutual understanding within a human community assumes its "rationalization" through creating by the members of this community an "integration platform of knowledge" shared by everybody, upon which they could, within a reasonable time, i.e. in the rate of situation development, make concerted decisions concerning the method to settle the current problem situation. In the Evergetics, the theory of intersubjective management performs the role of such a platform [7].

\section{Theory of intersubjective management}

Classical scientific theories accumulate objectively true knowledge acquired by scientists who research object as outside observers; everything being "subjectively colored" is not included in the theory. An approach to the study of management processes in society, implemented in this article on the principles of postnonclassical scientific rationality, leads to the need to review traditional ideas about the notion of "theory", which will require to use the concept of conventional truth of A. Poincaré, which treats the truth as a result of agreement [4].

Heterogeneous actors, identifying themselves in a problem situation, communicate with each other, united by the desire to make a decision acceptable to everybody concerning the way to settle the situation. Each of them is based on the subjective knowledge which is for him significant and 
"true" (relatively true). However, intersubjective consciousness enables them to jointly develop intersubjective knowledge, i.e. the knowledge that, being applied to this situation, is recognized as true by a limited number of actors as a result of their agreement. Intersubjective knowledge, being conventionally true, includes the results of the actors' agreements, on the basis of what principles, rules and regulations, the decisions about how to manage the situation will be made. These arrangements can be achieved by actors within the framework of the following types of intersubjectivity proposed in [23].

Semantic intersubjectivity implies clarity and common consent in regard to the notions and opinions constructed therefrom, i.e. they are understood equally by everybody and may therefore be used in the same manner.

Empirical intersubjectivity implies that the statements, based on empirical evidence, are taken as rationally justified. At that, the facts should be clearly understood, they must be acceptable and recognized by someone, i.e. the opinions, well-founded by facts and observations, are recognized to be necessary.

Logical intersubjectivity considers as rationally justified such statements, which are the result of logical inference. At that, intelligibility, clarity and overall acceptability are also assumed.

Operational intersubjectivity proceeds from the reproducibility of action and reasoning samples. It is assumed that a certain sequence of actions, always clear and acceptable without fail, is based on this sample. Individual elements of this technology and their sequence, constituting this sample, are clearly understood without alternative by everybody and, in principle, can be reproduced in the same form.

Normative intersubjectivity assumes a common acceptance of norms, rules of behavior and evaluation. If an activity is governed by norms, it is also considered as a rational basis. Although the norm is simultaneously a guide to action, and, in an operational sense, doesn't differ often from this last, but still the word "norm" is usually associated with certain value preferences.

In the conventionally true intersubjective knowledge, shared by all the actors who are aware of themselves in their common situation, thus, mutual understanding of heterogeneous actors is laid, since it is assumed that, as a result of negotiations, they must reach agreements on all the positions of five types of intersubjectivity. The whole body of knowledge, which, incidentally, may be represented by ontologies, may be considered as a "core" ad hoc of the theory of intersubjective management [7].

According to the theory of intersubjective management, the actors, should first make coordinated decisions on what tasks they need to put and achieve for settling the situation, i.e., to answer the eternal questions of "why?" and "what" to do. Due to different value preferences, they may have, because of it, differences and even conflicts. For the sake of being able to reach a consensus under these conditions, the heterogeneous actors should be in solidarity. Besides, solidarity, in the philosophy of R. Rorty, is the turn of mind (opposed to the traditional objectivity) to unite various points of view not on the platform of identity, but in the context of their differences. These differences, according to R. Rorty, provoke no world outlook conflicts, but create conditions for a free choice. No one among the positions united on the foundation of solidarity pretends to the status to be sole, and that distinguishes principally this approach from the classical rationality, based on the idea of possibility and accessibility of only one sole right decision. R. Rorty denies the need in a semantic centre, supposing that the social hope is called to be supported not by "objectivity" but by "solidarity" [24].

Thus, the theory of intersubjective management, created ad hoc by heterogeneous solidary actors, being in a problem situation, includes intersubjective knowledge acquired by the actors and related specifically to the situation in everyday life, as well as the consequences resulting from multilateral negotiations of the actors, where the tasks (together with criteria and restrictions) which 
must be achieved for settling the situation, are stated. In other words, the theory of intersubjective control is created in the world of everyday-life. This fact is extremely important, because in human society, the problems to be solved in the systems world should be "scooped" from the life-world, from the everyday-life.

\section{Holonic systems}

In order to solve the problems, the actors must mobilize available resources and get associated in systems, in which (in contrast to intersubjective communities) the composition of the elements is already defined and the relationship between them is regulated. Organization of systems may take place in different ways. Causal (cause-effect) organizing principle, used in bureaucratic systems, implies that the output result (effect) of a functional element is an input (cause) for the other. Such causal representations are successfully used in the construction of models of technical systems (machines, mechanisms, technological processes, automatic control systems, etc.), but are practically unacceptable in the processes to govern the society. To say more precisely, it is possible, but only in the case when a man performs a function ascribed rigidly to him, being reduced to a machine to convert the "input" to the "output". It may be an implementation of any instructions or a mechanical operation, achievement of a task under a given algorithm and input data, etc. In other words, the man is represented here as a "cog" in the bureaucratic machine. Therefore, the Evergetics, which consider the man as an integrity which is capable to perform cognitive activity-related functions and to interact with other integrities, must use the principle of "part-whole" as a basic principle of the systems composition [7].

"Building blocks" of such systems is a holon (from the Greek "holos" - the whole, entire - with the suffix "on", indicating a part, a particle) - a notion introduced by Arthur Koestler [25]. Holon is defined as a whole being a part of another whole, which includes components for processing, transporting and storing physical objects (substance, energy) and information. In holonic system, a holon is considered as an autonomous self-governing integrity, able to combine (integrate) with other holons in the constituent holons and, conversely, to decay (disintegrate). In contrast to the causal organization in which one element affects the other, holonic organization involves interaction between the elements. As an example, let us adduce holonic organization of a federal state.

Individuals ("atomic" holons) are combined in "family" holons, which form another integrity "settlement". Settlements are organized in "municipality" holons, composing, in turn, "subject of the federation". Finally, the subjects of the federation form a "state" holon. Each of these holons is sufficiently autonomous and is not a structural subdivision of a "superior body" holon. Nevertheless, they are able to agree on any joint activities and investment of resources in a common cause, if it seems meaningful to all holons (eg, construction of roads passing through the village, through the municipality and through the subject of the federation).

Holonic system is not rigidly fixed as a set of "forever given" elements and instructively described relationship between them, but is "cultivated" - let's emphasize this - "from bottom to top", on the basis of lowerarchy [26], when the "lower" elements are the source of resources and power for the "higher", in the contrast to a hierarchical organization "from top to bottom", based on dictates of the supreme power. For example, suppose that there are three holons, each of which includes an actor and tools for his activity. One specializes in the repair of electrical equipment, other - in plumbing, and the third - in household appliances. Working independently, they have found that they spend a lot of time searching for orders. The idea occurs to associate them in a constituent holon, and a new actor, hired on the mentioned below terms, should undertake administrative issues and search for orders. 
His salary will depend on how much money will bring in a "common pot" the electrician, the plumber and the repair mechanic, and they, in turn, agree to fulfill with high quality all the orders that their new "boss" will bring, to whom they have given commanding authority and financial resources. If he will work badly and, accordingly, number of orders will be not enough; his employers may make collectively a decision to dismiss him. In this example, where the intellectual resources of the actors are used in the management process, a "holonic structure" and "lowerarchy" are in function.

Bureaucratic organization is built on the causal principles and hierarchy. Here, everything begins not from the man, but from the structure, where a "function" and instructions for its implementation are prepared for each man, and a "boss" on the top of the hierarchy is endowed "from the top" with all the resources and powers. He hires "depersonalized" functionaries for his staff, passes them, on his discretion, some of these resources and powers, sets benchmarks for their activities and requires execution. Such a manager is under the control of his superiors only, who, by virtue of "corporate solidarity", will try to support him even when things in the organization will go really bad.

Value- and subject-oriented Evergetics, of course, should have in its arsenal the methods and means to build holonic systems, which open the opportunity to use intellectual and volitional resources of the people in the management processes in society. And if the Weber's "ideal bureaucracy" postulated disregard of personal qualities, the Evergetics, on the contrary, highlights the worldview issues. Would the decision-making be aimed "to the good" could the intensity of confrontation in the society be reduced, would the slogan "the end justifies the means" be cultivated no longer, etc. - the answers to these and other similar questions shall be defined precisely by what a man thinks, what are his value priorities, whether he is able to be flexible in discussing some controversial provisions in the "dialogue of cultures". In the Evergetics, the opportunity and the need for worldview discussions, where interests and standpoints of the homogeneous actors are conflicting, lie at the very initial stage, when the actors begin to produce intersubjective knowledge and discuss alternative options to find the way out of the problem situation in which they perceive themselves.

\section{The man of culture}

The "Economic Man" who appeared on the stage of history in the 18th century, may be called the first actor, acting for personal economic interests, but who, through the "invisible hand" of the market is involved in the welfare of all the nation. The concept of economic man, homo economicus, as is known, was developed by Adam Smith as the concept of an ideal type of the rational economic actor. While working for himself, the actor is simultaneously working for society. Such a mechanism of personal and public interests coordination will be called later by Kant "automaton" that provides "pathologically forced consent" in society by putting the task of humanizing it, turning it into a "moral". He will consider the movement in this direction as the main objective of the whole history of the mankind, which will always strive to approach it, but not having a chance to fully achieve it [26].

Karl Polanyi was the first, who aimed "to create theoretical basis for an ideal social order where the man is the core value" [27]. Polanyi proceeded from the fact that people interact with each other on the grounds of three principles: gift exchange (reciprocity), centralized redistribution and market. So, if market relationships involve mutual calculation of benefits and costs, the gifts exchange is performed without warranty of cost recovery in the future (we can only talk about expectations for any possible response actions). Nevertheless, as Polanyi believed, the market system, for its satisfactory operation, requires compliance with cultural (non-market) factors - honesty, industry, re- 
sponsibility, trust of partners, etc. The very same market system destroys these signs of culture, inherited from its previous socio-economic structures, contributing to instability of society. Therefore, K. Polanyi saw the ability to provide humane existence of mankind in the "cultural revolution, allowing to subordinate the economy to the human community" [27].

At the present time, the culture is considered as a "system of historically developing overbiological programs of human vital functions (activities, behavior and communication), providing reproduction and change of social life in all its major manifestations" [4]. In such a broad understanding, the culture includes morals, manners and customs, oral and writing language, science, technology, art, economy, statement of education, religion, socio-political organization of the society, etc. [28]. The culture not only preserves and transmits social experience, passing it from generation to generation, but also "generates new programs of activity, behavior and communication which, being realized in appropriate types and forms of human activity, generate actual variations in the life of society" [4].

The man, being a creature of culture, is, at the same time, its creator. He becomes a personality only through assimilation of social experience transmitted in the culture, but the man is able to invent new concepts and products of culture, which may match social needs. In this case, they are included into the culture and begin to program the activity of other people. An individual experience turns into a social one, so, new conditions and the phenomena appear in the culture, fixing this experience [24]. Therefore, a man who not only adheres to cultural norms, accepted in the society, (what "the cultured man" makes), but also is involved in the creation of new concepts and products of culture, may be called "the man of culture".

The man of culture is a key figure in the developing society which is situated "beyond socialism and capitalism" [26]. After all, more dynamic is a society; more value acquires the level of cultural creativity, addressed to the future [24]. In such society, each man of culture should aspire to augment personal cultural heritage made by him (and not to a simple personal enrichment) and, as consequence, to increase cultural potential of the society as a whole (and not only "the wealth of nations") with the help of "an invisible hand of culture".

The last thesis, essentially, is a modified classic formula of Adam Smith, which works in the modern world, too, "where the result and purpose of economic life are flows of goods and services, consumed by all", although in the "Wealth of Nations", he "turned to his epoch, expounding, in this work, the doctrine, which should help in governing the Empire" [29]. If we look far enough ahead, we can see an increasing role of culture (in a broad sense) in society, which is manifested, in particular, in the forms of innovative activity in practically all spheres of human life. This means that the survival society is being gradually transformed into a developing society, and the "Economic Man" - into the "Man of Culture" [2].

\section{Conclusion}

The main feature of the Evergetics as a value- and subject-oriented science is the inclusion of heterogeneous actors in the management processes, who perceive themselves to be in a common problem situation which is considered as a primary nonpartitionable integrity. Actors, having their own subjective views of the world and value priorities, develop intersubjective knowledge of the situation on the basis of which, using the debate and mutual persuasion, make joint coordinated decisions about what tasks need to be achieved for settling the situation, thus answering the question "why?" and "what?" to do. Classical value-invariant management science doesn't put such questions, but it brings into focus the search of answers to the question "how?" to better achieve the task that someone has put. Therefore, the Evergetics proceeds from the fact that at this early stage, "the 
birth of ideas" regarding alternative ways out of this situation lays the success of the cause, since a high price shall be paid for the idea "launched" in a wrong direction.

Methods and tools of the Evergetics, created by scientists and experts, should be appropriately focused on the effective use of intellectual and volitional resources of the people - actors, ensuring the achievement of mutual understanding among them and consensus. We are not talking about the identity of outlook and like-mindedness, but about the solidarity of heterogeneous actors, based on the concept of conventional truth of A. Poincaré and achieving consent within the five types of intersubjectivity of K. Hübner. Thus, the professionals create the methodology of Evergetics, and the actors use the developed methods and tools to acquire intersubjective knowledge and to control the situation, playing the role of "applied social theorists".

Appearance of the man, with his complex of social and humanitarian problems, in the spotlight of Evergetics renders interdisciplinary this science, since social, economic, psychological, pedagogical and many other issues are brought to the forefront. However, the problem of transformation of the "Economic Man" in the "Man of Culture" should be recognized strategically important.

\section{References}

[1] Wiener, N. Kibernetika i obschestvo [Cybernetics and Society] / N. Winer. - M.: Foreign Literature Publishing House, 1958. - 200 p. (In Russian).

[2] Vittikh, V.A. Evolution of Ideas on Management Processes in the Society: From Cybernetics to Evergetics / V.A. Vittikh // Group Decision and Negotiation. - http://link.springer.com/article/10.1007/s10726-014-94146/fulltext.html - Published online: 14 September 2014.

[3] Vittikh, V.A. Problemy Evergetiki [Problems of Evergetics] / V.A. Vittikh // Problemy upravleniya. 2014. No. 4. P. 69-71. (In Russian).

[4] Novaya filosofskaya enciklopediya [New Philosophical Encyclopedia] (in four volumes). - M.: Mysl, 2010. (In Russian).

[5] Zotov, A.F. Sovremennaya zapadnaya filosofiya [Contemporary Western Philosophy] / A.F. Zotov. - M.: Prospekt, 2010. - 608 p. (In Russian).

[6] Stepin, V.S. Filosofiya nauki i techniki [Philosophy of Science and Technology] / V.S Stepin., V.G. Gorokhov, M.A. Rozov. - M.: Gardarika, 1996. - 400 p. (In Russian).

[7] Vittikh, V.A. Introduction to the Theory of Intersubjective Management / V.A. Vittikh // Group Decision and Negotiation. 2015. Vol. 24. Issue 1. P. 67-95. - http://link.springer.com/article/10.1007/s10726-014-9380z/fulltext.html - Open Access Date: 09 March, 2014.

[8] Novikov, A.M. Metodologiya [Methodology] / A.M. Novikov, D.A. Novikov. - M.: SINTEG, 2007. - 668 p. (In Russian).

[9] Lepsky, V.E. Sub'ektivno-orientirovannyi podchod k innovatsionnomu razvitiyu [Subject-oriented Approach to Innovative Development] / V.E. Lepsky. - M.: "Kogito-Tsentr" Publishing House, 2009. - 208 p. (In Russian).

[10] Kukathas, $\boldsymbol{C}$. Liberal'nyi archipelag: teoriya raznoobraziya i svobody [The Liberal Archipelago: A Theory of Diversity and Freedom] / C. Kukathas. - M.: Mysl, 2011. - 482 p. (In Russian).

[11] Slovar' filosofskich terminov [Dictionary of Philosophical Terms]. - M.: INFRA, 2004. - 731 p. (In Russian).

[12] Habermas, J. Otnosheniya mezhdu sistemoi i zhiznennym mirom v usloviyakh pozdnego kapitalizma [The Relationship between the System and Life-World in the Conditions of Late Capitalism] / J. Habermas // Thesis. 1993. Issue 2. P. 123-136. (In Russian).

[13] Johnson, R.A. The Theory and Management of Systems (second edition) / R.A. Johnson, F.E. Kast, J.E. Rosenzweig. - N.Y.: McGraw Hill Book Company, 1967. (Translation into Russian: M.: Sovetskoye radio, 1971.- 648 p.).

[14] Yanitsky, O.N. Professional kak social'nyi actor: sluchayi ili pravilo? [A Professional as Social Actor: Occasion or Rule?] / O.N. Yanitsky // Vestnik instituta sotsiologii. 2012. No. 5. P. 43-60. (In Russian).

[15] Klimov, I.A. Sociologicheskaya koncepciya Anthony Giddens'a [Sociological concept of Anthony Giddens] / I.A. Klimov. - http://www.nir.ru/sj/sj/sj1-2-00klim.html - (In Russian).

[16] Noveishiyi sociologicheskiyi slovar' [Newest Sociological Dictionary]. - Minsk: Knizhny dom, 2010. - 1312 p.

[17] Vittikh, V.A. Heterogeneous Actor and Everyday Life as Key Concepts of Evergetics / V.A. Vittikh // Group Decision and Negotiation. - http://link.springer.com/article/10.1007/s10726-014-9423-5/fulltext.html - Published online: 29 November 2014. 
[18] Frolov, A.V. Fenomenologicheskaya teoriya intersub'ektivnosti kak metodologicheskaya osnova issledovaniya gorodskogo hozyastva [The Phenomenological Theory of Intersubjectivity as a Methodological Basis for the Study of Municipal Services] / A.V. Frolov // Scientific conference "Edmund Husserl. On the 150th Anniversary of the Birth of the Philosopher" (Reports). RAS Institute of Philosophy. - http://iph.ras.ru/page52532624.html (In Russian).

[19] Stivenson, J. Filosofiya [Philosophy] / J. Stivenson. - M.: AST Astrel, 2007. - 294 p. (In Russian).

[20] Vittikh, V.A. Fenomenologicheskiyi podchod k postroeniyu teorii upravleniya obschestvom [Phenomenological Approach to the Construction of the Theory of Social Management] / V.A. Vittikh // Proc. of XII All-Russian Conference on Management Problems. (June 16-19 2014, Moscow, Russia). - M.: IPU RAN, 2014. - P. $6182-6186$. (In Russian).

[21] Frankl, V. Chelovek v poiskakh smysla [Man's Search for Meaning] / V. Frankl. - M.: Kniga po trebovaniyu, 2012. - 366 p. (In Russian).

[22] Längle, A. Zhizn', napolnennaya smyslom. Logoterapiya kak sredstvo okazaniya pomoschi v zhizni [Life Full of Meaning. Logotherapy as Means of Assisting in Life] / A. Längle. - M.: Genesis, 2014. - 144 p. (In Russian).

[23] Hübner, K. Istina mifa [The Truth of the Myth] / K. Hübner. - M.: Respublika, 1996. - 448 p. (In Russian).

[24] Vsemirnaya encyklopediya: Filosofiya [World Encyclopedia: Philosophy]. - M.: AST, Minsk: Harvest, Sovremenny Literator, 2001. - 1312 p. (In Russian).

[25] Koestler, A. The Ghost in the Machine / A. Koestler. - London: Arcana Books, 1989. - 384 p.

[26] Ackoff, R.L. Za predelami socializma i kapitalizma: razvivayuscheesya obschestvo [Beyond Socialism and Capitalism: Developing Society] / R.L. Ackoff // Problemy upravleniya v socialnykh sistemakh. 2009. Vol. 1. Issue 1. P. 112-140. (In Russian).

[27] Rozinskaya, N.A. Vvedenie. Trudy i dni Karla Polan'i (1886-1964) [Introduction. Works and Days of Karl Polanyi (1886-1964)] / N.A. Rozinskaya, Yu.V. Latov // In the book: "The Great Transformation" of Karl Polanyi: Past, Present and Future / Ed.: R.M. Nureyev. - M.: State University-HSE, 2007. - P. 11-21. (In Russian).

[28] Filosofskiyi enciklopedicheskiyi slovar' [Philosophical Encyclopedic Dictionary]. - M.: INFRA-M, 1997. - 576 p. (In Russian).

[29] Heilbroner, R.L. Filosofy ot mira sego [Philosophers of this World] / R.L. Heilbroner. - M.: Astrel, CORPUS, 2011. - 432 p. (In Russian).

\title{
ПРОЛЕГОМЕНЫ К ЭВЕРГЕТИКЕ
}

\section{В.А. Виттих}

Институт проблем управления сложными системами РАН, Самара, Россия vav1940@gmail.com

\section{Аннотация}

Излагаются предварительные замечания и разъясняющее введение (пролегомены) к эвергетике - ценностно- и субъектно-ориентированной науке о процессах управления в обществе. Резервы повышения эффективности управления эвергетика ищет не в модернизации «обезличенной» бюрократической машины, а в самих людях, в каждом человеке, в использовании его интеллектуальных и волевых ресурсов. Человек рассматривается в ней не как «винтик» ценностно-инвариантного управленческого механизма, а как личность (актор), наделённая сознанием, действующая рационально и выполняющая познавательно-деятельностные функции вместе с другими людьми по урегулированию проблемных ситуаций, возникающих в повседневной жизни. Эти неоднородные акторы, имеющие свои субъективные взгляды на мир и ценностные приоритеты, опираясь на концепцию конвенциональной истины А. Пуанкаре, трактующую истину как результат соглашения, вырабатывают интерсубъективые знания, на основе которых принимают совместные решения о том, какие задачи нужно решать для урегулирования ситуации. Постижение смысла ситуации у каждого неоднородного актора происходит на уровне индивидуального сознания. Однако один человек не в состоянии конституировать всё многообразие смыслов ситуации, поэтому он воспринимает от других то, чего не достаёт в его собственном опыте. Смыслопорождающая деятельность людей оказывает влияние на всё интерсубъективное сообщество, в результате чего образуется общее смысловое пространство. В эвергетике используется холонический подход (по принципу «частьцелое») к построению систем в отличие от традиционного каузального (по принципу «причина-следствие»). В
\end{abstract}


статье подчёркивается стратегическая значимость проблемы трансформации «экономического человека» в «человека культуры».

Ключевые слова: эвергетика, управление процессами в обществе, гетерогенный актор, повседневность, интерсубъективность, проблемная ситуация, феноменология, холоническая система, человек культуры.

\section{Сведения об авторе}

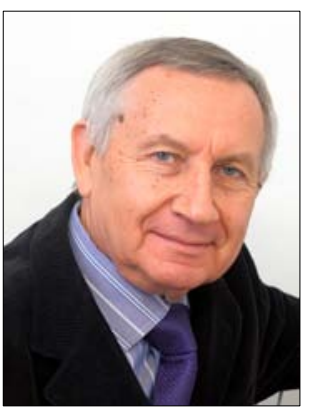

Виттих Владимир Андреевич, 1940 г. рождения. Окончил Куйбышевский индустриальный институт (ныне Самарский государственный технический университет) в 1962 г., д.т.н. (1976), профессор (1976). Научный советник Института проблем управления сложными системами РАН, заведующий кафедрой инженерии знаний Поволжского государственного университета телекоммуникаций и информатики, член Научного совета Российской академии наук по теории управляемых процессов и автоматизации. В списке научных трудов более 280 работ (в том числе 5 монографий) по проблемам управления и моделирования в сложных системах.

Vladimir Andreevich Vittikh (b. 1940) graduated from Kuybyshev Industrial Institute (at present Samara State Technical University) in 1962, D.Sc.Eng. (1976), professor (1976). Scientific counselor of the Institute for the Control of Complex Systems of RAS, Head of the knowledge engineering department at Povolzhskiy State University of Telecommunication and Informatics, member of the scientific council on the theory of the controlled processes and the automation of the RAS. He is the author (co-author) of more than 280 publications (among them 5 monographs) deals with the complex systems, control, management and modeling problems. 